ISSN 1412 - 3681

\title{
How is The Volatility of Jakarta Islamic Index Stocks?
}

\author{
ERNA LISTYANINGSIH ${ }^{1}$, CHANDRASEKHAR KRISHNAMURTI ${ }^{2}$
}

\author{
${ }^{1}$ Department of Management, Universitas Malahayati, Kemiling, Bandar Lampung 35153, Indonesia \\ ${ }^{2}$ School of Commerce, University of Southern Queensland, Toowoomba, Queensland 4350, Australia \\ Email correspondence: ernatya04@yahoo.com, Chandrasekhar.Krishnamurti@usq.edu.au
}

\begin{abstract}
The Jakarta Islamic Index (JII) is the Islamic Index in Indonesia which is based on Sharia compliance, changes in market capitalisation and liquidity. This objective of the present study is to measure volatility of JII stocks and compare it with non-JII during 2005-2012 by using ARCH and GARCH models. The previous studies just comparing JII with other indices, a valid conclusion cannot be drawn as most of stocks belonging to $\mathrm{Jll}$ are also included in the other indices. Therefore in this study we split stocks listed in Indonesian stock exchange into two periods: 2005-2007 which consists of two groups: JII and Non-JII and 2008-2012 which consists of three groups: JII, Sharia and Non-Sharia based on industry sector in order to investigate which one has the lowest volatility. This study uses two proxies of liquidity for each period namely: turnover and spread due to we use CAPM extended Fama and French and also augmented liquidity to calculate excess return. In the period of 2008-2012 found that there is GARCH $(1,0)$ in which ARCH influences the volatility of return. Additionally, dummy-JII and dummy-Sharia influence negative significantly toward volatility of return as well. This finding also revealed that $\mathrm{JI}$ stocks have lower volatility compared to non-JII in which $\mathrm{JII}$ has the lowest leverage compared to Sharia and Non-Sharia. Therefore this result is consistent with the theory in which JII stocks has the lowest volatility due to their characteristic which is Sharia compliance, high market capitalization and high liquidity.
\end{abstract}

Key words: JII, volatility, matching data.

\section{Bagaimana Volatilitas dari Saham Jakarta Islamic Index ?}

\begin{abstract}
Abstrak
The Jakarta Islamic Index (JII) adalah Indeks Islam di Indonesia yang didasarkan pada kepatuhan syariah, perubahan kapitalisasi pasar dan likuiditas. Tujuan ini dari penelitian ini adalah untuk mengukur volatilitas saham JII dan membandingkannya dengan non-Jll selama 2005-2012 dengan menggunakan ARCH dan GARCH model. Penelitian sebelumnya hanya membandingkan JII dengan indeks lainnya, kesimpulan yang valid tidak dapat ditarik karena kebanyakan dari saham milik JII juga termasuk dalam indeks lainnya. Oleh karena itu dalam penelitian ini kami membagi saham yang tercatat di bursa Indonesia menjadi dua periode: 2005-2007 yang terdiri dari dua kelompok: JII dan Non-JII dan 2008-2012 yang terdiri dari tiga kelompok: JII, Syariah dan Non-Syariah berdasarkan industri sektor dalam rangka untuk menyelidiki mana yang memiliki volatilitas terendah. Penelitian ini menggunakan dua proxy likuiditas untuk setiap periode yaitu: turnover dan menyebar karena kita menggunakan CAPM diperpanjang Fama dan likuiditas Perancis dan juga ditambah untuk menghitung excess return. Pada periode 2008-2012 menemukan bahwa ada GARCH $(1,0)$ di mana ARCH mempengaruhi volatilitas return. Selain itu, boneka-JII dan dummy-Syariah mempengaruhi negatif signifikan terhadap volatilitas return juga. Temuan ini juga mengungkapkan bahwa saham JII memiliki volatilitas yang lebih rendah dibandingkan dengan non-JII di mana JII memiliki leverage terendah dibandingkan dengan Syariah dan Non-Syariah. Oleh karena itu hasil ini konsisten dengan teori di mana saham JII memiliki volatilitas terendah karena karakteristik mereka yang memenuhi Syariah, kapitalisasi pasar yang tinggi dan likuiditas yang tinggi.
\end{abstract}

Kata kunci: JII, volatilitas, mencocokan data. 


\section{INTRODUCTION}

Stocks market volatility is related to the general health of economy, one interpretation of this evidence is that it is caused by financial leverage (Schwert, 1989). During good times, funds that use more leverage have higher profits, increasing their wealth and making them dominant in the market. However, if a downward price fluctuation occurs while one or more funds is fully leveraged, the resulting margin call causes them to sell into an already falling market, amplifying the downward price movement, therefore more leverage will cause substantial losses and leads volatility (Thurner et.al, 2012). In addition, Ross (1989) argues that volatility can be regarded as a measure of information flow. Furthermore, Eagle and $\mathrm{Ng}$ (1993) found that negative shocks introduce more volatility than positive shocks. Meanwhile, Bekaert and Wu (2000) argue that volatility reduces in the aftermath of good news but increases in the case of bad news. On the other hand Domowitz et.al (2001) who analyse the inter-relationships between liquidity, equity trading costs and volatility and then investigate the impact of these variables on equity returns found that increased volatility, acting through costs, reduces a portfolio's return. However, higher volatility reduces turnover as well, mitigating the impact of higher costs on returns. In general, volatility is a measure of the extent to which stock price can go up or down (fluctuating) quickly in a short span of time. The higher the volatility, the greater the stock price changes from day to day. One of approaches used for modelling volatility is the Autoregressive Conditional Heteroscedasticity (ARCH)/ Generalized Autoregressive Conditional Heteroscedasticity (GARCH) framework developed by Bollerslev (1986).

Previous studies that investigated Islamic indices from the perspective of volatility are as follows: Dharani and Natarajan (2008) who investigated Islamic index in India found that Nifty Sharia has low volatility compared to the broad Nifty Index. In addition, Akhtar et.al (2012) found that characteristics of Islamic financial markets reduce volatility linkages between Islamic and conventional stocks, bonds and bills. However, this result is contrary to the findings of Charles et.al (2011) in which they reported that the Dow Jones Islamic Index (DJII) and conventional ones have been equally affected by sudden changes in volatility. On the other hand Yusof and Abdulmajid (2007) who investigated the extent to which the conditional volatilities of both Islamic and conventional indexes in Malaysia are affected by monetary policy variables and found that interest rate volatility affects conventional stocks but not the Islamic stocks market volatility. Their finding concludes that interest rate is not a significant variable in explaining stock market volatility (Hakim and Rashidian, 2002). They used GARCH model together with VAR analysis conducted with monthly data during period January 1992 to December 2000.

Meanwhile, in Indonesia, the study of Jakarta Islamic Index (JII) stocks conducted from the volatility perspective. Kurniawan (2008), Maskur (2009) showed that JII stocks have high volatility comparable to the other indices in Indonesia such as LQ 45 and IHSG. However, previous studies focussed on comparing of Jll stocks with other indices such as Jakarta Composite Index (JCl) or Index Harga Saham Gabungan (IHSG) which is as Indonesian market index and LQ45 which is 45 most liquid stocks. Therefore, a valid conclusion cannot be drawn as most of the stocks belonging to JII are also included in these indices.

In sum, there is no clear evidence regarding whether Islamic investment is less or more volatile than conventional ones. Therefore, we cannot draw a final conclusion about this issue. Nevertheless, due to their characteristics, Sharia stocks have unique characteristics based on Sharia selection restriction, namely leverage ratio, where in firms are not allowed to have debt ratio or total debt to total asset ratio more than $33 \%$ in DJII while JII uses $45 \%$. Regarding the financial ratio, JII stocks. are less restrictive than the other market such as US, Malaysia and India. The bigger the ratio, it means the bigger dependence on debt. Nevertheless, zero debt or full compliance is not possible. In addition, Islamic equity funds possess some specific risks that are usually not present in conventional investments such as: changing Sharia rules, the lack of sufficient track record, high exposure to companies that might be sub-optimally levered, and companies with low working capital (Hayat and Kraeussl, 2012).

Additionally, Girard and Hassan (2008) argue that Islamic indices comprise smaller firms than 
conventional indices. In sum, Islamic indices are growth and small-cap oriented while conventional indices are relatively more value and mid-cap focused. However, Al-Zoubi and Maghyereh (2007) found that Islamic index presents unique risk characteristics. The examination reflects a risk level that is significantly less than the broad market basket of stocks (Hakim and Rashidian, 2002). In addition, Hakim and Rashidian (2002) indicate that Islamic index is influenced by factors independent from the broad market or interest rates. Therefore, this study is interesting because previous studies have a mix results, not clear and scarce as well. In addition, JII stocks have unique characteristics besides being based on Islamic principles. They have high market capitalization and high liquidity.

We split stocks listed in Indonesian stock exchange into two periods: 2005-2007 which consist of two groups: JII and Non-JII and 2008-2012 which consist of three groups: JII, Sharia and Non-Sharia based on industry sector. Our contribution of this study is that we measure volatility of JII stocks and compare it with Non-Jll stocks (Sharia and Non-Sharia) and also investigate which one has the lowest volatility from three groups namely: III, Sharia and Non-Sharia. We expect that JII stocks will have lower volatility compared to Sharia and Non-Sharia stocks due to their characteristics which is Sharia compliance in which has lower leverage than non-Sharia, high market capitalisation and high liquidity. We also extend our investigation by calculating leverage ratio and Return on Assets (ROA) to investigate which one has the most volatile and the highest return. We expect that JII stocks will have the lowest leverage ratio and the highest ROA. We designed ARCH / GARCH model to capture these features. No previous studies conducted on this issue. Therefore it will provide new insight regarding this issue.

The rest of the paper is organised as follows. The next section discusses Jakarta Islamic Index and Sharia selection restriction in order to understand how a stock becomes member of Jakarta Islamic Index and hypothesis development. The next section, we describe the method employed in this paper. After that is the section of result and discussion and the last section is our conclusion.

\section{LITERATURE REVIEW}

In IDX (accessed on 20th of February 2015), there are twenty five indices, namely: Agriculture; Mining; BasicInd; Miscellaneous Industry; Consumer; Property; Infrastructure; Finance; Trade; Manufacture; JCl; LQ45; JII; Main Board Index; Development Board Index; KOMPAS100; BISNIS-27; PEFINDO25; SRIKEHATI; Indeks Saham Syariah Indonesia (ISSI); Infobank15; IDX30; Investor33; MNC36 and SMInfra 18.

$\mathrm{JII}$ is the stock index of Sharia compliant stocks in Indonesia. The objective of the JII is to provide a vehicle for investors to invest in Sharia compliant stocks. Every period, 30 stocks which meet the Islamic criteria are included in JII. JII was launched on July 3, 2000. However, in order to generate longer historical data, the base date for calculation of $\mathrm{JII}$ is using January 2, 1995 with index base number of 100 (IDX, 2012).

The milestones of the development of Sharia capital market in Indonesia was started on July 3rd, 2000 by the issuance of JII. Even though PT Danareksa Investment Management had previously launched a Danareksa Sharia on July 3, 1997, due to the SelfRegulatory Organizations (SRO) it has not issued an official instrument related to Sharia Securities, the developments of Sharia capital market is not yet reckoned until the issuance of JII ( see Appendix 1) (IDX, 2012).

Determination of criteria used in the selection of shares in the JII is done by the Sharia Supervisory Board of PT DIM. Stocks that enter JII should first pass the Sharia filter which has two screenings: core business criteria and financial ratios criteria. Furthermore, JII selection process is performed by IDX based on the performance of Sharia shares trading (see Appendix 2) for Jll screening process information). However, in terms of financial constraints, the Dow Jones Islamic Index (DJII) is the most conservative in this regard. Stocks included in DJII must not have debt ratio exceeding 33\%, accounts receivables to total assets must remain below $45 \%$ and interest income should represent less than $5 \%$ of total revenue (Hakim and Rashidian, 2002). JII is less restrictive and requires upper limits of $45 \%, 55 \%$ and $10 \%$ respectively for 
debt ratio, accounts receivables to total assets and interest income to revenue.

IDX conducts reviews on JII every six months, adjusted with the periodic of DES issuance by Bapepam-LK. After the selection of Sharia stocks by Bapepam-LK, which is released as DES, IDX continues the selection process based on its trading performance. JII is published on regular basis on January and June each year. Before November 2007, Jll selection is only based on JII selection either Sharia or trading performance. Therefore, before November 2007, Sharia stock was only 30 stocks which are incorporated in $\mathrm{JII}$.

The most important difference between Islamic or Sharia and other ethical investment principles is that besides excluding particular sectors, Islamic funds do not deal in the fixed-income market, and the receipt and payment of interest is not permitted (Hussein and Omran, 2005). Selection criteria should be used when determining which companies are acceptable from the point of view of Islamic investors (Wilson, 1987). Hassan et.al (2005) argue that it is not true that Islamic ethical criteria will be always lead to good performance, nor will it always lead to bad performance. Based on Sharia selection restriction, namely leverage ratio, where in firms are not allowed to have debt ratio or total debt to total asset ratio more than $33 \%$ in DJII while JII uses $45 \%$. Therefore, it is expected that Sharia stocks will have a lower volatility than conventional stocks (Dharani and Natarajan, 2005).

Previous studies found that Sharia stocks have lower volatility than conventional stocks (Akhtar et.al, 2011), Dharani and Natarajan (2008) and Yusof and AbdulMajid (2007). However, another studies found that there is no different volatility between Sharia stocks and conventional stocks (Charles et.al, 2011), Kurniawan (2008) and Maskur (2009). Due to the lack of Sharia stock volatility studies, therefore there is no clear evidence regarding whether Islamic investment is less or more volatile than conventional ones. Additionally, previous studies which linking liquidity with volatility: higher liquidity is generally associated with lower volatility and trading costs (Chordial et.al, 2001), Damowitz et.al, 2001) and Li and Wu (2006).

In the Indonesian capital market context, the stocks that are included in JII besides being based on Sharia selection restriction also based on Indonesian Stock Exchange (IDX) performance process in which from Sharia stocks, IDX selects 60 stocks based on the last year's market capitalisation and from 60 top stocks by market capitalisation, IDX selects 30 top stocks based on their last year's level of liquidity in regular market. Thus, it is expected that JII stocks will be less volatile than non JII stocks because JII stocks consist of blue chip stocks with high market capitalization and high liquidity and also have a lower leverage than non-JII. Therefore, it is expected that it will be less affected by sudden shocks compared to non JII stocks. Our study examines the relation important of Sharia compliance which is ethical compliance and liquidity effect on volatility. We therefore posit the following hypothesis:

\begin{tabular}{|l|l|}
\hline H1. & $\begin{array}{l}\text { Jll stocks will have lower volatility compared to } \\
\text { non-Sharia stocks. }\end{array}$ \\
\hline H2. & $\begin{array}{l}\text { Jll stocks will have lower volatility compared to } \\
\text { Sharia stocks }\end{array}$ \\
\hline H3. & $\begin{array}{l}\text { Sharia stocks will have lower volatility } \\
\text { compared to non-Sharia }\end{array}$ \\
\hline
\end{tabular}

Previous studies in Indonesia just focus on comparing the volatility between JII stock and other indices. However, in this study we investigate the volatility of JII stocks and non JII stocks (Sharia and non-Sharia or conventional) by using the GARCH model. To the best of our knowledge, this study has not been conducted previously in Indonesia. We expect to gain substantial insights by using more sophisticated methodology to compare the volatility of JII with non-JII stocks.

\section{METHOD}

This study investigates the volatility of $\mathrm{JI}$ and non JII using the ARCH/GARCH model of Bollerslev (1986) and Bollerslev et.al (1994). This model used is: $\sigma_{t}^{2}=\omega+\alpha \varepsilon_{t-1}^{2}+\beta \sigma_{t-1}^{2}$

Additionally, we add dummy variable to investigate whether JII and Sharia influence the volatility in IDX during the research period. We add the dummy, estimate the model below:

$\sigma_{t}^{2}=\omega+\alpha \varepsilon_{t-1}^{2}+\beta \sigma_{t-1}^{2}+\nu_{1}$ DJII $+\gamma_{2}$ D-Sharia ..... 
Where $\sigma_{t}^{2}$ is a function of constant average variance $(\omega)$, the issues (news) of volatility of previous period which is measured as the lag of the square residual of the mean equation, $\varepsilon_{t-1}^{2}$ (the ARCH term), and the past variance $\sigma_{\mathrm{t}-1}^{2}$ (the GARCH term), DJII and D-Sharia represent respectively the dummy variables for the first and second variable control, DJII = 1 and the others or Sharia and Non-Sharia $=0$ and D-Sharia $=1$, the others or $\mathrm{Jll}$ and Non-Sharia $=0$.

$\sigma_{\mathrm{t}}^{2}=\omega+\alpha \varepsilon_{\mathrm{t}-1}^{2}+\beta \sigma_{\mathrm{t}-1}^{2}$

Additionally, we add dummy variable to investigate whether JII and Sharia influence the volatility in IDX during the research period. We add the dummy, estimate the model below:

$\sigma_{t}^{2}=\omega+\alpha \varepsilon_{t-1}^{2}+\beta \sigma_{t-1}^{2}+\gamma_{1}$ DJII $+\gamma_{2}$ D-Sharia ......

Where $\sigma_{t}^{2}$ is a function of constant average variance $(\omega)$, the issues (news) of volatility of previous period which is measured as the lag of the square residual of the mean equation, $\varepsilon_{t-1}^{2}$ (the ARCH term), and the past variance $\sigma_{\mathrm{t}-1}^{2}$ (the GARCH term), DJII and D-Sharia represent respectively the dummy variables for the first and second variable control, DJII $=1$ and the others or Sharia and Non-Sharia $=0$ and D-Sharia $=1$, the others or $\mathrm{Jll}$ and Non-Sharia $=0$.

To measure excess return we use Fama \& French three factors model augmented with liquidity:

For period 2005-2007:

$R_{i t}-R_{f t}=\alpha_{i}+\beta_{1 i}\left(R_{m t}-R_{f t}\right)+\beta_{2 i} S M B_{t}+\beta_{3 i} H M L_{t}+\beta_{4 i} L_{i q}$ $+\beta_{5 i} l+e_{i t}$.

For period 2008-2012:

$R_{i t}-R_{f t}=\alpha_{i}+\beta_{1 i}\left(R_{m t}-R_{f t}\right)+\beta_{2 i} S M B_{t}+\beta_{3 i} H M L_{t}+\beta_{4 i} L_{i q}+$ $\beta_{5 i} l+\beta_{6 i} l+e_{i t}$.

Where Rt indicates stock returns on trading month $\mathrm{t}$ and $\beta_{1} \ldots \beta_{6}$ are the regression coefficient of variables ( $\left(R_{m}-R_{f}\right), S M B, H M L$, Liq, I and $\left.S\right)$ such as market return, Small Minus Big, High Book to market Minus Low Book to market, Liquidity, Dummy-JII, Dummy-Sharia and $e_{i t}$ is the error term. This regression coefficient shows the average stock return on trading month $t$. I shows dummy Jll stocks (JII stocks $=1$ and the others or the non-Jll stocks $=0$ ) and S shows dummy Sharia stocks (Sharia stocks $=1$ and the others or non-Sharia and $\mathrm{JII}=0$ ).
We include dividends to calculate stock return following Damodaran (2001):

$$
R_{i t}=\frac{P_{i t}-P_{i t-1}+D_{t}}{P_{i t-1}}
$$

$\mathrm{R}_{\mathrm{it}}$ indicates stock return $\mathrm{i}$ on trading month $\mathrm{t}, \mathrm{P}_{\text {it }}$ is price of stock $i$ at the closing month and $D_{t}$ is dividend on stock $i$ in month $t$ and $P_{i t-1}$ is price of stock $i$ on the closing month before.

Liquidity will be measured by using two proxies: firstly, by using turnover ratio in which trading volume divided by number of shares outstanding and secondly, by using bid-ask spread from daily high and low prices (Corwin and Schultz, 2012).

The formulation of trading volume activity by Lo and Wang (2000).

\section{Amount of firm stock j which is traded in time t}

$\operatorname{TV} A_{i t}=$

Amount of outstanding stocks of firm $\mathrm{j}$ in time $t$

The formula of bid-ask spread by Corwin and Schultz (2012) is as below:

$$
S=\left(\frac{2\left(e^{\alpha}-1\right)}{1+e^{\alpha}}\right)
$$

Where $\mathrm{S}$ denotes bid-ask spread and e is exponential.

Where

$$
\alpha=\frac{\sqrt{2 \beta}-\sqrt{\beta}}{3-2 \sqrt{2}}-\sqrt{\frac{\gamma}{3-2 \sqrt{2}}},
$$

and

$\beta=\sum_{j=1}^{1}\left[\ln \left(\frac{H_{t+1}^{0}}{L_{t+1}^{0}}\right)\right]^{2}$

, which is sum of expected squared ratio of high and low prices ratio for two consecutive

days. Gamma $(\gamma)$ equals to $\left[\ln \left(\frac{H_{t, t+1}^{0}}{L_{t, t+1}^{0}}\right)\right]^{2}$ ratio of high and low prices over a range of two days.

This study uses monthly closing price and market capitalisation of JII and Non-Jll during 2005 up to 2012. However, we split into two periods: for 20052007 and 2008-2012.

We use monthly market capitalisation for matching 
data. For the first period from 2005 up to 2007 we divided data into 2 groups, namely; JII and Non-JII. In addition, based on the information of announcement date of JII from IDX mentioned that in 2005 up to 2007, Jll announced the announcement of $\mathrm{Jl}$ list each period was on the end of December and June, so that's why we applied one period is six month: from January-June and July-December. However starting from 2008, we began to divide data into 3 groups: JII, Non JII-Sharia and Non JII Non-Sharia. In 2008, JII began to apply announcement of JII every the early of December last year up to May the following year (six months) and the early of June up to November (six months). However, especially in 2008, it began from January 2008 till May 2008 due to the announcement of last year was on 27 of December 2007. Subsequently, period 1 is from December of last year up to May the following year and period 2 is from June up to November (each period is 6 months). Then, we calculate the average of monthly market cap of each period of each stock based on industry sector. Therefore, each year has two periods namely: period 1 and period 2. From 2005 up to 2007, period 1 is from January - June and Period 2 is from July December in each year. However, from $2008-2012$, Period 1 is from December last year up to May in the following year and Period 2 is from June - November in each year. Furthermore, all data are retrieved from Datastream.

This study is interesting because previous studies just focussed on comparing of $\mathrm{Jl}$ with other indices such as IHSG, LQ45, Kompas 100 etc. However, a valid conclusion cannot be drawn as most of stocks belonging to $\mathrm{JII}$ are also included in the other indices. Therefore, in this research, we employ elaborate matching data. Firstly, we split stocks at IDX into two periods: period of 2005-2007 which contains two groups: III and Non-JII and period of 2008-2012 which contains three groups: JII, Sharia and Non-Sharia based on industry sector. There are two screening process to enter JII: firstly, Sharia selection namely core business and financial ratio and secondly, trading performance selection namely market capitalization and liquidity (see Screening Process, Appendix 2). Secondly, we clasify those groups based on industry sector each period. Next, each group of each period sort based on market capitalisation (+/- $10 \%$ up to $20 \%$ ) and lastly, sort proportionally based on market capitalisation for each group and each period. In this study employs monthly market capitalisation, for 2005 up to 2012. We used Eviews 7 to measure the volatility of JII stocks and non-JII stocks.

\section{RESULT AND DISCUSSION}

We use Eviews to generate descriptive statictics, mean model-residual of graph, the output from ARCH test and finally the ARCH/GARCH model. We also test the stationary of the data with Augmented Dickey-Fuller (ADF) test and all the result is stationary (see Appendix 3). In this study, we split the sample into two periods: period of 2005-2007 and period of 2008-2012. Each period, we also split into two due to using two proxies of liquidity namely: turnover and spread.

\section{Period 2005-2007: for group with turnover liquidity} proxy

Form descriptive statistics on Table 1, we got mean of excess return is -0.054820 with maximum value is 0.265000 and minimum value is -0.305400 .

Table 1 Descriptive Statistics

\begin{tabular}{cc}
\hline & Excess Return 2005-2007 \\
\hline Mean & -0.054820 \\
Median & -0.060386 \\
Maximum & 0.265000 \\
Minimum & -0.305400 \\
Std. Dev. & 0.083549 \\
Skewness & 0.311196 \\
Kurtosis & 5.861943 \\
Jarque-Bera & 25.73426 \\
Probability & 0.000003 \\
Sum & -3.947042 \\
Sum Sq. Dev. & 0.495608 \\
Observations & 72 \\
\hline
\end{tabular}

Futhermore, from residual of figure, we should have a clustering volatility to continue running the ARCH/ GARCH model. From the Figure 1 reported that from the $1^{\text {st }}$ month up to around $44^{\text {th }}$ month, there is a period of low volatility followed by a period of high volatility. Furthermore, from 45th month, there is period of low volatility followed by a period of high volatility. Therefore, there is no clustering volatility. However, we have to make sure whether there is $\mathrm{ARCH}$ effect in this model, then we test ARCH effect 


\section{JURNAL BISNIS \& MANAJEMEN}

ISSN 1412 - 3681

in this model by using $\mathrm{ARCH}$ test or Breusch-PaganGodfrey-ARCH test.

From result on Table 2 reported that there is no $\mathrm{ARCH}$ effect in this model. Because the value of probability is more than $10 \%$. We can try by using other method presented on Table 3.

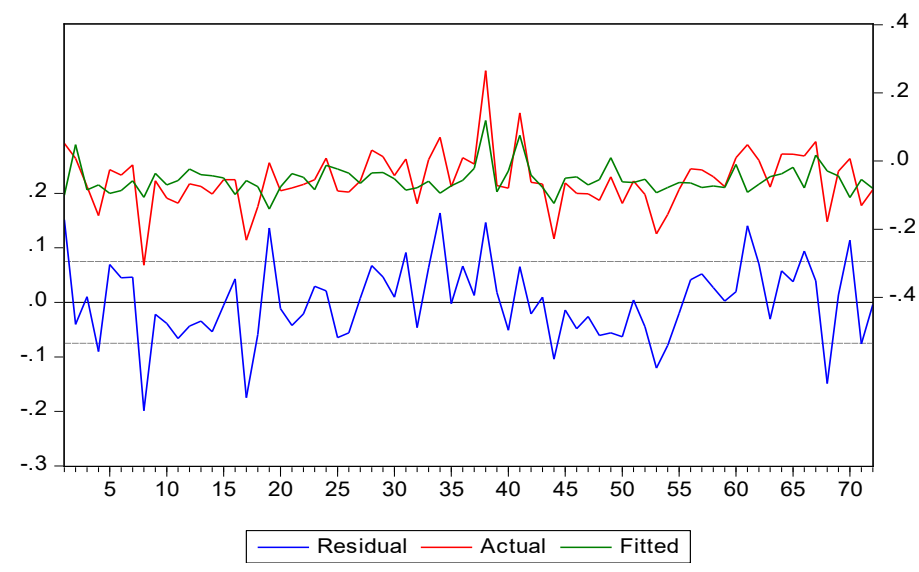

Figure 1 Residual

Table 2 ARCH Test

\begin{tabular}{lcll}
\hline \multicolumn{2}{l}{ Heteroskedasticity Test: ARCH } & & \\
\hline F-statistic & 2.513477 & Prob. F(1,69) & 0.1174 \\
Obs*R-squared & 2.495430 & Prob. Chi-Square(1) & 0.1142 \\
\hline
\end{tabular}

Table 3 ARCH Test

\begin{tabular}{lccc}
\hline \multicolumn{4}{l}{ Heteroskedasticity Test: Breusch-Pagan-Godfrey } \\
\hline F-statistic & 1.802572 & Prob. F(4,67) & 0.1386 \\
Obs*R-squared & 6.995536 & Prob. Chi-Square(4) & 0.1361 \\
Scaled explained SS & 6.992634 & Prob. Chi-Square(4) & 0.1363 \\
\hline
\end{tabular}

However, the result is the same (see Table 3) in which there is no ARCH effect in this model, because $p$-value of Obs*R-squared is not significant. Therefore, the period of 2005-2007 for turnover liquidity proxy can not continue to develop GARCH model due to no $\mathrm{ARCH}$ effect.

\section{Period 2005-2007: for group with spread liquidity proxy}

Futhermore, from residual of graph, we should have a clustering volatility to continue running the $\mathrm{ARCH} /$ GARCH model. From the Figure 2 reported that from $1^{\text {st }}$ month up to $43^{\text {th }}$ month, there is a period of low volatility followed by a period of high volatility.
Furthermore, there is a period of low volatility up to $56^{\text {th }}$ month followed by a period of high volatility. Therefore, there is no clustering volatility. However, we have to make sure whether there is $\mathrm{ARCH}$ effect in this model, then we test $\mathrm{ARCH}$ effect in this model by using $\mathrm{ARCH}$ test or Breusch-Pagan-Godfrey-ARCH test

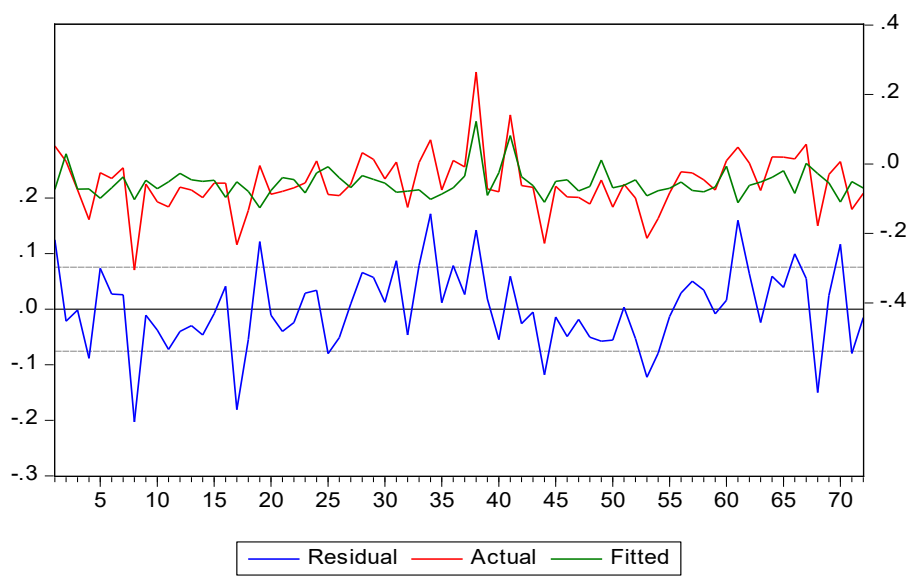

Figure 2 Residual

From result on Table 4 reported that there is no $A R C H$ effect in this model. Because the value of probability is more than $10 \%$. We can try by using other method presented on Table 5.

Table 4 ARCH Test

\begin{tabular}{|c|c|c|c|}
\hline \multicolumn{4}{|c|}{ Heteroskedasticity Test: ARCH } \\
\hline F-statistic & 2.319025 & Prob. $F(1,69)$ & 0.1324 \\
\hline Obs*R-squared & 2.308651 & Prob. Chi-Square(1) & 0.1287 \\
\hline
\end{tabular}

However, the result is the same (see Table 5) in which there is no ARCH effect in this model. Therefore, period of 2005-2007 for liquidity proxy is spread can not continue to develop GARCH model. Because $p$-value of Obs*R-squared is not significant.

Table 5 ARCH Test

\begin{tabular}{lccc}
\hline \multicolumn{4}{l}{ Heteroskedasticity Test: Breusch-Pagan-Godfrey } \\
\hline F-statistic & 1.735850 & Prob. F(4,67) & 0.1524 \\
Obs*R-squared & 6.760910 & Prob. Chi-Square(4) & 0.1491 \\
Scaled explained SS & 6.991887 & Prob. Chi-Square(4) & 0.1363 \\
\hline
\end{tabular}

Period 2008-2012: for group turnover liquidity proxy Form descriptive statistics on Table 6 , we got mean of return is -0.033000 with maximum value is 0.383975 and minimum value is -0.468221 . 
Table 6 Descriptive Statistic

\begin{tabular}{cc}
\hline & Excess Return 2005-2007 \\
\hline Mean & -0.054820 \\
Median & -0.060386 \\
Maximum & 0.265000 \\
Minimum & -0.305400 \\
Std. Dev. & 0.083549 \\
Skewness & 0.311196 \\
Kurtosis & 5.861943 \\
Jarque-Bera & 25.73426 \\
Probability & 0.000003 \\
Sum & -3.947042 \\
Sum Sq. Dev. & 0.495608 \\
Observations & 72 \\
\hline
\end{tabular}

Futhermore, from residual of figure 3, we should have a clustering volatility to continue running the ARCH/GARCH model. From the Figure 3 reported that from the $1^{\text {st }}$ month up to $15^{\text {th }}$ month, there is a period of low volatility followed by a period of high volatility up to around $35^{\text {th }}$ month. Futhermore, there is a period of low volatility followed by a period of low volatility up to around $86^{\text {th }}$ month. Next, from $87^{\text {th }}$ month, there is a period of high volatility followed by a period of high volatility. Therefore, there is a clustering volatility. However, we have to make sure whether there is $\mathrm{ARCH}$ effect in this model, then we test ARCH effect in this model by using ARCH test or Breusch-Pagan-Godfrey-ARCH test.

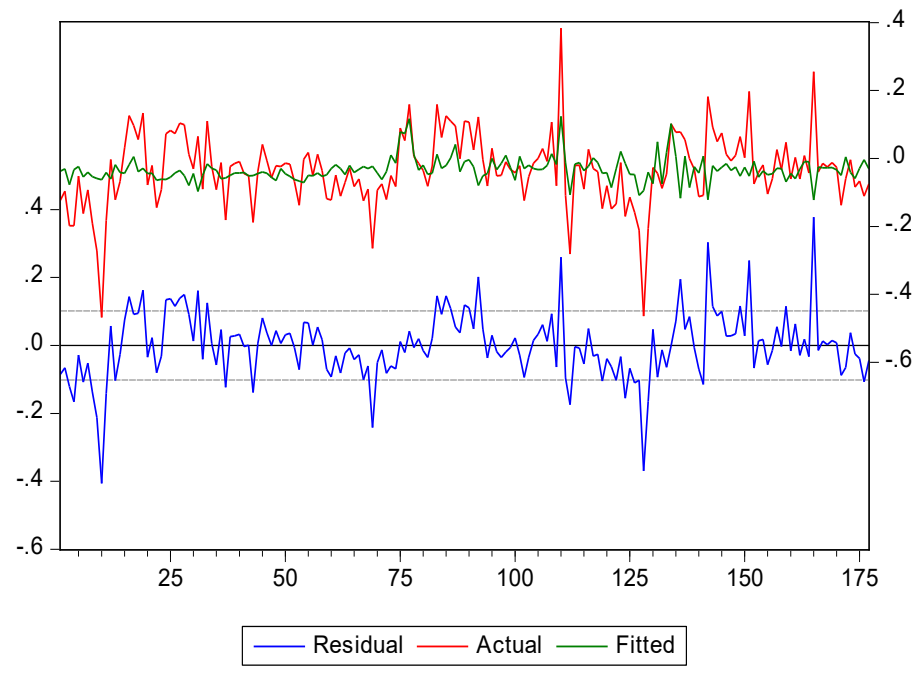

Figure 3 Residual

From result on Table 7 reported that there is no $\mathrm{ARCH}$ effect in this model. Because the value of probability is more than $10 \%$. We can try by using other method presented on Table 8.

Table 7 ARCH Test

\begin{tabular}{|c|c|c|c|}
\hline \multicolumn{4}{|c|}{ Heteroskedasticity Test: ARCH } \\
\hline F-statistic & 1.912572 & Prob. $F(1,174)$ & 0.1684 \\
\hline Obs*R-squared & 1.913522 & Prob. Chi-Square(1) & 0.1666 \\
\hline
\end{tabular}

However, from Table 8, the result reported that there is ARCH effect in this model. Therefore, period of 20082012 when liquidity is proxied by turnover we can run GARCH model, because p-value of Obs*R-squared is significant at $1 \%$. Therefore, we can continue to develop GARCH model to investigate which variable can influence the volatility of excess return.

Table 8 ARCH Test

\begin{tabular}{lccc}
\hline \multicolumn{4}{l}{ Heteroskedasticity Test: Breusch-Pagan-Godfrey } \\
\hline F-statistic & 5.395829 & Prob. F(5,171) & 0.0001 \\
Obs*R-squared & 24.12026 & Prob. Chi-Square(5) & 0.0002 \\
Scaled explained SS & 55.49428 & Prob. Chi-Square(5) & 0.0000 \\
\hline
\end{tabular}

From running of GARCH model, we got the variance equation (see Table 9), although the coefficient of $\mathrm{ARCH}$ and $\mathrm{GARCH}$ are positive but Adjusted $\mathrm{R}$ squared value is negative, then we try to run $A R C H 1$ or $G A R C H$ $(1,0)$ Model.

Table 9 Variance Model: GARCH $(1,1)$

Dependent Variable: EXRETURN 2008-2012 Method: ML - ARCH (Marquardt) - Normal distribution GARCH = C(7) + C(8)*RESID (-1)^2 + C(9)*GARCH(-1) + C(10)*DUMMYJII + C(11)*DUMMYSHARIA

\begin{tabular}{lcccc}
\hline \multicolumn{1}{c}{ Variable } & Coefficient & Std. Error & z-Statistic & Prob. \\
\hline \multicolumn{5}{c}{ Variance Equation } \\
\hline C & 0.009825 & 0.003675 & 2.673682 & 0.0075 \\
RESID(-1)^2 & 0.547073 & 0.199390 & 2.743739 & 0.0061 \\
GARCH(-1) & 0.194977 & 0.189875 & 1.026868 & 0.3045 \\
DUMMYJII & -0.006823 & 0.003241 & -2.105301 & 0.0353 \\
DUMMYSHARIA & -0.008380 & 0.003300 & -2.539300 & 0.0111 \\
\hline Adjusted R-squared & -0.002009 & & & \\
Akaike info criterion & -1.765706 & & & \\
Schwarz criterion & -1.568319 & & & \\
\hline
\end{tabular}

From two models presented, ARCH1/GARCH $(1,0)$ model in Table 10 is the best model because it has the lowest AIC (Akaike info criterion) and SIC (Schwarz criterion). The result from variance equation indicates 
that $\mathrm{ARCH}$ effect can influence positive significantly on the volatility (excess return) during 2008-2012. In addition, Dummy-JII and Dummy-Sharia can influence volatility as well but negatively.

Table 10 Variance Model: GARCH $(1,0)$

Dependent Variable: EXRETURN 2008-2012

Method: ML - ARCH (Marquardt) - Normal distribution GARCH $=C(7)+C(8) *$ RESID $(-1)^{\wedge} 2+C(9) * D U M M Y J I I+C(10)$ *DUMMYSHARIA

\begin{tabular}{lcccc}
\hline \multicolumn{1}{c}{ Variable } & Coefficient & Std. Error & z-Statistic & Prob. \\
\hline \multicolumn{4}{c}{ Variance Equation } \\
\hline C & 0.012457 & 0.002979 & 4.181603 & 0.0000 \\
RESID $(-1)^{\wedge} 2$ & 0.592000 & 0.185570 & 3.190165 & 0.0014 \\
DUMMYII & -0.007354 & 0.003333 & -2.206843 & 0.0273 \\
DUMMYSHARIA & -0.010102 & 0.002953 & -3.420350 & 0.0006 \\
\hline \multicolumn{1}{c}{ Adjusted R-squared } & 0.014459 & & & \\
$\quad$ Akaike info criterion & -1.765602 & & & \\
$\quad$ Schwarz criterion & -1.586158 & & & \\
\hline
\end{tabular}

\section{Result of Leverage Calculation}

Additionally, we also employ additional test in order to support our finding in ARCH/GARCH model which one has the lowest leverage and the highest Return on Assets (ROA) in relation with this issue. Therefore, in this study, we calculated leverage and ROA each period. The result of leverage calculation among three groups in period of 2008-2012 and two groups in period of 2005-2007 found are the following:

\section{Period: 2005-2007}

Table 14 ROA and Leverage calculation

\begin{tabular}{lrrrrrrr}
\hline ROA & $\mathbf{2 0 0 5 , 1}$ & $\mathbf{2 0 0 5 , 2}$ & $\mathbf{2 0 0 6 , 1}$ & $\mathbf{2 0 0 6 , 2}$ & $\mathbf{2 0 0 7 , 1}$ & $\mathbf{2 0 0 7 , 2}$ & Average \\
\hline JII & 9.01 & 8.94 & 9.27 & 7.49 & 12.08 & 12.59 & 9.90 \\
Non-JII & 6.35 & 5.85 & 9.11 & 9.04 & 7.58 & 8.59 & 7.75 \\
Leverage & 2005,1 & 2005,2 & 2006,1 & 2006,2 & 2007,1 & 2007,2 & Average \\
JII & $34.48 \%$ & $35.49 \%$ & $27.91 \%$ & $27.85 \%$ & $27.25 \%$ & $25.23 \%$ & $29.70 \%$ \\
Non-JII & $25.11 \%$ & $26.75 \%$ & $29.56 \%$ & $26.67 \%$ & $24.06 \%$ & $32.74 \%$ & $27.48 \%$ \\
\hline
\end{tabular}

ROA is return on assets.

Leverage is total debt to total assets.

Due to in this period there was no ARCH effect either for proxy of turnover or spread, therefore we do not discuss about this issue further although we present the result of calculation of leverage and ROA in this period.

\section{Period: 2008-2012}

Higher leverage means more volatile. In the 20082012 periods, JII has the lowest leverage than the other groups. Additionally, from previous result of $\mathrm{ARCH}$ and $\mathrm{GARCH}$ model found that all groups is volatile because it is found $A R C H$ in their model. However, based on leverage calculation revealed that $\mathrm{JII}$ has the lowest leverage and the highest ROA. It means that JII has the lowest volatility compared to Non-JII (Sharia and Non-Sharia). This finding supports that JII stocks will have lower volatility compared to non-Jll.

\section{Table 15 ROA and Leverage calculation}

\begin{tabular}{lccccccccccc}
\hline ROA & 2008,1 & 2008,2 & 2009,1 & 2009,2 & 2010,1 & 2010,2 & 2011,1 & 2011,2 & 2012,1 & 2012,2 & Average \\
\hline III & 13.33 & 12.50 & 11.92 & 13.18 & 13.35 & 13.17 & 14.38 & 16.19 & 18.73 & 20.82 & 14.76 \\
Sharia & 10.41 & 8.08 & 7.04 & 8.04 & 8.54 & 10.81 & 15.88 & 11.01 & 13.31 & 11.20 & 10.43 \\
$\begin{array}{l}\text { Non- } \\
\text { Sharia }\end{array}$ & 6.84 & 5.56 & 0.80 & -1.74 & 8.21 & 7.34 & 8.54 & 10.09 & 10.63 & 9.94 & 6.62 \\
Leverage & 2008,1 & 2008,2 & 2009,1 & 2009,2 & 2010,1 & 2010,2 & 2011,1 & 2011,2 & 2012,1 & 2012,2 & Average \\
JII & $12.00 \%$ & $16.16 \%$ & $15.99 \%$ & $16.96 \%$ & $16.35 \%$ & $16.45 \%$ & $12.46 \%$ & $16.70 \%$ & $16.24 \%$ & $13.67 \%$ & $15.30 \%$ \\
Sharia & $19.08 \%$ & $19.90 \%$ & $18.18 \%$ & $16.11 \%$ & $16.63 \%$ & $12.50 \%$ & $13.87 \%$ & $16.37 \%$ & $13.97 \%$ & $21.15 \%$ & $16.78 \%$ \\
& & & & & & & & & & & \\
$\begin{array}{l}\text { Non- } \\
\text { Sharia }\end{array}$ & $25.96 \%$ & $38.93 \%$ & $38.12 \%$ & $31.02 \%$ & $35.98 \%$ & $38.01 \%$ & $33.88 \%$ & $36.39 \%$ & $37.02 \%$ & $39.85 \%$ & $35.51 \%$ \\
\hline ROA & & & & & & & & & & &
\end{tabular}

ROA is return on assets.

Leverage is total debt to total assets.

In summary, based on the ARCH/GARCH model test and based on result of additional test which presented in Table 15, we found that there was a volatility on the period of 2008-2012, and we found which one has the lowest leverage and the highest Return on Assets (ROA) in relation with this issue. Therefore, this findings support Hypothesis 1 which states that JII stocks will have lower volatility compared to non-Sharia stocks, and also supports Hypothesis 2 which states that JII stocks will have lower volatility compared to Sharia stocks in where JII stocks have lower leverage which mean lower volatility than Sharia stocks . In addition, this findings also support Hypothesis 3 which states that Sharia stocks will have lower volatility compared to non-Sharia in where Sharia stocks have lower leverage which mean lower volatility than non-Sharia stocks.

Overall the results of this reseach support the previous research in where Sharia stocks have a lower volatility than non Sharia stock (Dharani and Natarajan, 2008). In other words, this results is consistent with the 
previous work. However, this study is different with the previous reseach in where we added additional test to support which one has the lowest volatility. Our result implies that JII has the lowest volatility compared to non-JII (Sharia and non-Sharia), and Non-Sharia (conventional) has the highest volatility.

This result also implies that JII stocks are less risky than conventional stocks. This finding is consistent with the finding of Al-Zoubi, H. A., \& Maghyereh, A. I. (2007) who found that DJII is less risky than conventional stocks (DJ World Index).

In sum, these findings support the hypothesis $\mathrm{H} 1, \mathrm{H} 2$ and $\mathrm{H} 3$, which states that JII stocks will have lower volatility compared to non-Sharia stocks, JII stocks will have lower volatility compared to Sharia stocks, and Sharia stocks will have lower volatility compared to non-Sharia respectively.

These findings indicate that although, in this study, we devided the sample into 3 groups namely: JII stocks which has 30 Sharia stocks that have high market capitalisation and high liquidity, Sharia stocks which do not include in JII stocks and non-Sharia stocks but these findings is consistent with the previous studies. Based on Sharia selection restriction, namely leverage ratio, where in firms are not allowed to have debt ratio or total debt to total asset ratio more than $45 \%$. Higher leverage means more volatile. Therefore, Sharia stocks have a lower volatility than conventional ones. Furthermore, Jll stocks which have the lowest leverage than Sharia stocks and non-Sharia stocks, due to Sharia screening process (see Appendix 2) have the lowest volatility than the other stocks. Additionally, Sharia stocks which have a lower leverage than nonSharia stocks, have a lower volatility compared to non-Sharia stocks.

\section{CONCLUSION}

In this study we measure volatility of JII stocks, Sharia Stocks and Non-Sharia Stocks. We investigate the performance of JII and Non-JII (Sharia and NonSharia) stocks from volatility perspective. Interestingly in this study is that we employ matching data based on industry sector then we divided the stocks in IDX two periods: 2005-2007 period which contains stocks of $\mathrm{JI}$ and Non-JII and 2008-2012 period which contain stocks of JII, Sharia and Non-Sharia. Each period then we split again become two because we have two proxies of liquidity namely: turnover and spread.

We found that for 2005-2007 period, there was no ARCH effect either for proxy of turnover or spread, therefore we cannot continue running ARCH/GARCH model. However, for 2008-2012 period, we found that there was an ARCH effect on turnover proxy and spread proxy. We also found that both of them has GARCH $(1,0)$, which means that ARCH influenced the volatility of excess return in period of 2008-2012. Additionally, dummy-Jll and dummy-Sharia influence negatively toward volatility of excess return as well. It means that in period of 2008-2012 either group with turnover liquidity proxy or group with spread proxy is volatile. In sum, in this period, ARCH model is good to be applied than GARCH model.

On the other hand, according the result of leverage calculation of each period found that in the 2005-2007 period, JII has higher leverage than non-Jll. However, in this period, there was no clustering volatility. In addition, after testing by using ARCH test, it was found that there was no ARCH effect. Therefore, we can't say which one is more volatile in this period. Furthermore, in the 2008-2012 periods, we found that JII has the lowest leverage than the other groups and Non-Sharia has the biggest leverage in this group. It means that JII has the lowest volatility compared to Non-JII (Sharia and Non-Sharia). This finding supports that JII stocks will have lower volatility compared to Non-JII. Therefore, this finding is consistent with the theory in where JII stocks will be less volatile than non-JII (Sharia and Non-Sharia) stocks because JII stocks consist of blue chip stocks with high market capitalization and liquidity and also have a lower leverage than non-Sharia stocks. Additionally, we also found that Sharia stocks have a lower leverage than Non-Sharia stocks. It means that Sharia stocks have a lower volatility than Non-Sharia due to Sharia compliance.

These results provide theoretical, practical guidelines and contribution of $\mathrm{JII}$ performance from volatility assessment perspective, therefore it is expected that these results can become a useful guidelines for researchers and also for investors regarding volatility of Sharia stocks. 
This study measure the volatility of stocks due to Sharia reason and due to changes in market capitalisation and liquidity and also leverage. However, it is difficult to figure out other non-Sharia factors due to data limitation. Therefore, for further research, this study suggest to examine of non-Sharia criteria such as deviation of core business activity into non-acceptable lines.

\section{REFERENCES}

Akhtar, S., Jahromi, M., John, K., \& Moise, C. (2011). 'Intensity of Volatility Linkages between Islamic and Conventional Markets'. In AFA 2012 Chicago Meetings Paper: proceedings of the AFA 2012 Chicago Meetings Paper. Chicago

Al-Zoubi, H. A., \& Maghyereh, A. I. (2007). The relative risk performance of Islamic finance: A new guide to less risky investments. International Journal of Theoretical and Applied Finance, 10, 2, 235-49

Bekaert, G., \& Wu, G. (2000). Asymmetric volatility and risk in equity markets. Review of Financial studies, 13, 1, 1-42

Bollerslev, T. (1986). Generalized autoregressive conditional heteroskedasticity. Journal of econometrics, 31, 3, 07-27

Bollerslev, T., Engle, R. F., \& Nelson, D. B (eds). (1994). $A R C H$ models, 4, in The Handbook of Econometrics, Elsevier B.V., California.

Charles, A., Darné, O., \& Pop, A. (11-13 May 2011). 'Are Islamic Indexes more Volatile than Conventional Indexes? Evidence from Dow Jones Indexes'. In proceedings of thelnternational Conference of the French Finance Association (AFFI), French, <http:// dx.doi.org/10.2139/ssrn.1836751>.

Chordia, T., \& Swaminathan, B. (2000). Trading volume and cross autocorrelations in stock returns, The Journal of Finance, 55, 2, 91335
Chordia, T., Roll, R., \& Subrahmanyam, A. (2001). Market liquidity and trading activity. The Journal of Finance, 56, 2, 501-30.

Corwin, S. A., \& Schultz, P. (2012). A simple way to estimate bid-ask spreads from daily high and low prices. The Journal of Finance, 67, 2, 719-59

Damodaran, A. (2001). Corporate finance:theory and practice, 2 edn, John Wiley \& Son, Inc., United States of America

Dharani, M., \& Natarajan, P. (2008). Equanimity of Risk and Return Relationship between Shariah Index and General Index in India. Journal of Economics and Behavioral Studies, 2, 5, 213-22

Domowitz, I., Glen, J., \& Madhavan, A. (2001). Liquidity, volatility and equity trading costs across countries and over time. International Finance, 4, 2, 221-55

Engle, R. F., \& Ng, V. K. (1993). Measuring and testing the impact of news on volatility. Journal of Finance, 48, 5, 1-31

Girard, E. C., \& Hassan, M. K. (2008). Is There a Cost to Faith-Based Investing: Evidence from FTSE Islamic Indices. The Journal of Investing, 17, 4, 112-21

Guo, W. C., Wang, F. Y., \& Wu, H. M. (2011). Financial leverage and market volatility with diverse beliefs. Economic Theory, 47, 23, 337-64

Hakim, S., \& Rashidian, M. (2002). Risk and return of Islamic stock market indexes. In Economic Research Forum Annual Meetings: proceedings of theEconomic Research Forum Annual Meetings Sharjah, UEA

Hassan, A., Antoniou, A., \& Paudyal, D. K. (2005). Impact of Ethical Screening on Investment Performance: The Case of the Dow Jones Islamic Index. Islamic Economic Studies, 12, 2, 67-97 
Hayat, R., \& Kraeussl, R. (2011). Risk and return characteristics of Islamic equity funds. Emerging Markets Review, 12, 2, 189-203

Hussein, K., \& Omran, M. (2005). Ethical Investment Revisited. The Journal of Investing, 14, 3, 105-26

IDX, (2012). Sharia stock. Retrieved from <http:// www.idx.co.id/Home/ProductAndServices/ ShariaMarket/ShariaProducts/tabid/157/ language/id-ID/Default.aspx>.

IDX, (2012). Sharia Milestone, Retrieved from <http://www.idx.co.id/Home/ ProductAndServices/ShariaMarket/ Milestone/tabid/201/language/en-US/ Default.aspx>.

JII, 2012. Retrieved from <http://www.idx.co.id/ Home/ProductAndServices/ShariaMarket/ ShariaProducts/tabid/157/language/id-ID/ Default.aspx>.

Kaustia, M. (2004). Market-wide impact of the disposition effect: evidence from IPO trading volume. Journal of Financial Markets, 7, 2, 207-35

Kurniawan, T. (2008). Volatilitas saham Syariah (analisis atas Jakarta Islamic Index). KARIM Review, Special Edition, 41-6

Li, J., \& Wu, C. (2006). Daily Return Volatility, Bid-Ask Spreads, and Information Flow: Analyzing the Information Content of Volume. The Journal of Business, 79, 5, 2697-739

Lo, A. W., \& Wang, J. W. (2000). Trading volume: Definitions, data analysis, and implications of portfolio theory, National Bureau of Economic Research

Lynch, A., W \& Mendenhall, R. R. (1997). New Evidence on Stock Price Effects Associated with Changes in the S\&P 500 Index. The Journal of Business, 70, 3, 351-83

Mackey, A., Mackey, T. B., \& Barney, J. B. (2007). Corporat social responsibility and firm performance: investor preference and corporate strategies. Academy of Management Review, 32, 3, 817-35

Maskur, A. (2009). Volatilitas harga saham antara saham konvensional dan Syariah', Dinamika Keuangan Dan Perbankan, 1, 2, 82-94

Ross, S. A. (1989). Information and Volatility: The No-Arbitrage Martingale Approach to Timing and Resolution Irrelevancy. Journal of Finance, 44, 1, 1-17

Schwert, G. W. (1989). Why does stock market volatility change over time. The Journal of Finance, 44, 5, 1115-53

Thurner, S., Farmer, J. D., \& Geanakoplos, J. (2012). Leverage causes fat tails and clustered volatility. Quantitative Finance, 12, 5, 695707

Wilson, R. (1997). Islamic finance and ethical investment. International Journal of Social Economics, 24, 11, 1325-42

Yusof, R. M., \& AbdulMajid, S. (2007). Stock Market Volatility Transmission in Malaysia: Islamic Versus Conventional Stock Market. Islamic Economics, 20, 2, 17-35 
Appendix 1 Milestone of the development of Sharia capital market in Indonesia

Below are milestone of Sharia market development in Indonesia until today:

\begin{tabular}{|c|c|}
\hline [2000] & Jakarta Islamic Index (JII) \\
\hline [2001] & $\begin{array}{l}\text { Fatwa No. 20/DSN-MUI/IX/2001 concerning Guidelines for } \\
\text { the implementation of Investment for Sharia Mutual Funds. }\end{array}$ \\
\hline [2002] & $\begin{array}{l}\text { Fatwa No. 32/DSN-MUI/IX/2002 concerning Sharia Bonds } \\
\text { Fatwa No. 33/DSN-MUI/IX/2002 concerning Mudharabah } \\
\text { Sharia Bonds. }\end{array}$ \\
\hline [2003] & $\begin{array}{l}\text { Fatwa No. 40/DSN-MUI/X/2003 concerning Capital Market } \\
\text { and Guidelines for the implementation of Sharia Principles in } \\
\text { the Capital Market. MOU between Bapepam \& LK and DSN- } \\
\text { MUI }\end{array}$ \\
\hline [2004] & Fatwa No. 41/DSN-MUI/III/2004 concerning ljarah Sharia \\
\hline [2006] & $\begin{array}{l}\text { Bapepam \& LK Regulation No IX.A.13 concerning Issuance of } \\
\text { Sharia Securities } \\
\text { Bapepam \& LK Regulation No IX.A.14 concerning Contracts } \\
\text { Used for the Issuance of Sharia Securities in Capital Market. }\end{array}$ \\
\hline [2007] & $\begin{array}{l}\text { Fatwa No. 59/DSN-MUI/V/2007 concerning Mudharabah } \\
\text { Sharia Bonds Conversion } \\
\text { Bapepam \& LK No II.K.1 Regulation concerning Criteria and } \\
\text { Issuance of Sharia Securities List. }\end{array}$ \\
\hline [2008] & $\begin{array}{l}\text { Fatwa No. 65/DSN-MUI/III/2008 concerning Sharia Pre } \\
\text { Emptive Rights } \\
\text { Fatwa No. 66/DSN-MUI/III/2008 concerning Sharia Warrants } \\
\text { Fatwa No. 69/DSN-MUI/VI/2008 concerning SBSN } \\
\text { Fatwa No. 70/DSN-MUI/VI/2008 concerning Issuance } \\
\text { Method of SBSN } \\
\text { Fatwa No. 71/DSN-MUI/VI/2008 concerning Sale and Lease } \\
\text { Back } \\
\text { Fatwa No. 69/DSN-MUI/VI/2008 concerning Sale and Lease } \\
\text { Back of Ijarah SBSN } \\
\text { Law (UU) No. } 19 \text { Year } 2008 \text { concerning Government Sharia } \\
\text { Securities (SBSN) }\end{array}$ \\
\hline [2011] & $\begin{array}{l}\text { Fatwa No. } 80 / \mathrm{DSN}-\mathrm{MUI} / \mathrm{III} / 2011 \text { concerning The } \\
\text { Implementation of Sharia } \\
\text { Principles in the Equity Trading Mechanism at the Stock } \\
\text { Exchanges Regular Market. } \\
\text { Indonesia Sharia Stock Index (ISSI) } \\
\text { Sharia Online Trading System }\end{array}$ \\
\hline
\end{tabular}

\section{Appendix $2 \mathrm{JII}$ Screening Process}

Under the direction of the Sharia Supervisory Board of PT DIM, there are 6 conditions that must be met for these stocks to fulfil core business criteria (IDX) :

A. The company does not conduct any business activities (core business criteria), as referred in item 1.b of the Regulations of Bapepam-LK No. IX.A.13, business that conflict with Sharia Principles, such as :

1. Gambling and games considered as gambling.

2. Trading that is prohibited according to Sharia, such as :

a. Trading that is not followed by delivery/transfer of products and or services;

b. Trading with a fake offer or demand; and
3. Ribawi financial services, such as:
a. interest-based bank; and
b. interest-based finance company

4. Buying and selling of risks that involve speculation (gharar) and gambling (maisir)

5. Producing, distributing, trading, and or providing:

a. products or services that are forbidden because of its contents (haram li-ghairihi)

b. products or services that are forbidden not because of its contents but because they are stated forbidden by DSN-MUI; and or

c. products or services that can deprave one's morals and are harmful; and or

6. Transactions that contain elements of bribery (risywah)

B. The company fulfils /meets the following financial ratios criteria:

1. The ratio of interest-based liabilities to total assets is not more than $45 \%$

2. The ratio of interest income and other non-Sharia income to total revenue is no more than $10 \%$.

To become eligible for entering in the JII index, besides filters based on Sharia, stocks that enter the JII should be through some screening process. Below is the JII selection process performed by IDX based on the performance of Sharia shares trading (JII) :

1. Selected stocks are stocks that are included in DES issued by Bapepam \& LK

2. From these Sharia stocks, IDX select 60 top stocks based on the last year's market capitalization;

3. From these 60 top stocks by market capitalization, IDX will then select 30 top stocks based on their last year's level of liquidity in the regular market.

Review is conducted every six months for the determination of the index components at the beginning of January and July each year. While major changes to types of business issuer will be monitored continuously on the basis of publicly available data. The company that changed the lines of business and becomes inconsistent with the principles of Sharia will be excluded from the index. The issuers of stocks issued will be replaced by other stock. All these procedures aim to eliminate the speculative stocks. Some speculative stocks have an average level of liquidity in regular trading value of high and low levels of market capitalization. 
Appendix 3 Table 1A \& 1B: ADF Test for period 20052007 and Table 2A \& 2B: ADF Tesr for period 20082012

Table 1.A: ADF Test of Return for The Period: 2005-2007 Turnover Liquidity Proxy

Null Hypothesis: Return has a unit root Exogenous: Constant

Lag Length: 0 (Automatic - based on SIC, maxlag=11)

\begin{tabular}{lccc}
\hline & t-Statistic & Prob. $^{*}$ \\
\hline Augmented Dickey-Fuller test statistic & -7.407695 & 0.0000 \\
\hline Test critical values: & 1\% level & -3.525618 & -3.525618 \\
& $5 \%$ level & -2.902953 & -2.902953 \\
& $10 \%$ level & -2.588902 & -2.588902 \\
\hline
\end{tabular}

*MacKinnon (1996) one-sided p-values.

Table 1.B: ADF Test of Return for the Period: 2005-2007 Spread Liquidity Proxy

Null Hypothesis: Return has a unit root Exogenous: Constant Lag Length: 0 (Automatic - based on SIC, maxlag=11)

\begin{tabular}{lccc}
\hline & t-Statistic & Prob.* $^{*}$ \\
\hline \multicolumn{1}{l}{ Augmented Dickey-Fuller test statistic } & -7.728168 & 0.0000 \\
\hline Test critical values: & 1\% level & -3.525618 & -3.525618 \\
& $5 \%$ level & -2.902953 & -2.902953 \\
& $10 \%$ level & -2.588902 & -2.588902 \\
\hline
\end{tabular}

*MacKinnon (1996) one-sided p-values.
Table 2.A: ADF Test of Return for The Period 2008-2012 Turnover Liquidity Proxy

Null Hypothesis: Return has a unit root Exogenous: Constant Lag Length: 0 (Automatic - based on SIC, maxlag=13)

\begin{tabular}{lccc}
\hline & & t-Statistic & Prob. $^{*}$ \\
\hline Augmented Dickey-Fuller test statistic & -8.463503 & 0.0000 \\
\hline Test critical values: & 1\% level & -3.467633 & -3.525618 \\
& 5\% level & -2.877823 & -2.902953 \\
& $10 \%$ level & -2.575530 & -2.588902 \\
\hline
\end{tabular}

*MacKinnon (1996) one-sided p-values.

Table 2.B: ADF Test of Return for The Period 2008-2012 Spread Liquidity Proxy

Null Hypothesis: Return has a unit root Exogenous: Constant Lag Length: 0 (Automatic - based on SIC, maxlag=13)

\begin{tabular}{lccc}
\hline & t-Statistic & \multicolumn{1}{c}{ Prob. $^{*}$} \\
\hline Augmented Dickey-Fuller test statistic & -8.463503 & 0.0000 \\
\hline Test critical values: & 1\% level & -3.467633 & -3.525618 \\
& $5 \%$ level & -2.877823 & -2.902953 \\
& 10\% level & -2.575530 & -2.588902 \\
\hline
\end{tabular}

*MacKinnon (1996) one-sided p-values. 